\title{
INTERNATIONAL JOINT VENTURE BETWEEN ASEAN AND GULF: BIDDING AND DELIVERING BAHRAIN INTERNATIONAL FORMULA-1 CIRCUIT
}

\author{
Hamzah Abdul-Rahman', Chen Wang², Lincoln C. Wood ${ }^{3}$, \\ and Suraya Ismail ${ }^{2}$ \\ ${ }^{1}$ International University of Malaya-Wales, Malaysia, ${ }^{2}$ University of Malaya, \\ Malaysia, and ${ }^{3}$ Auckland University of Technology, New Zealand
}

\begin{abstract}
A foreign contractor can resort to a partnering or joint-venture strategy with a host contracting firm to bid for a major international construction project. This paper presents a case study in the Bahrain FORMULA-1 Circuit (BFC) project focusing mainly on its tendering and construction stages, which is lacking in literatures. Findings illustrate that the success in such an international pact include: advanced technical and engineering expertise; selection of a committed partner; management expertise; creating and sustaining good working environment; appropriate risk management; maintaining a reliable international materials supply chain; and efficient project planning and tracking system. Management expertise is the most important factor because of the peculiarities and problems of international projects. This case study is able to assist practitioners to devise their own approach in overcoming the challenges and dynamic influences in the international construction market.
\end{abstract}

Keywords: International Joint Venture, ASEAN \& GULF, developing countries, tendering, Bahrain, FORMULA-1 Circuit

DOI: $10.3176 / \operatorname{tr} .2014 .4 .04$

\section{Introduction}

It is interesting to note that international contracting firms manage to secure sufficient workload that makes their initiatives worthwhile (Ye et al. 2013). International joint ventures are mostly project-specific in nature (Kim et al. 2009, Hung et al. 2002, Chou and Yang 2013). The Bahrain FORMULA-1 Circuit is considered as one of the best international racing car track in terms of technical aspects and architectural quality (an aerial shot in Fig. 1). Two FORMULA-1 


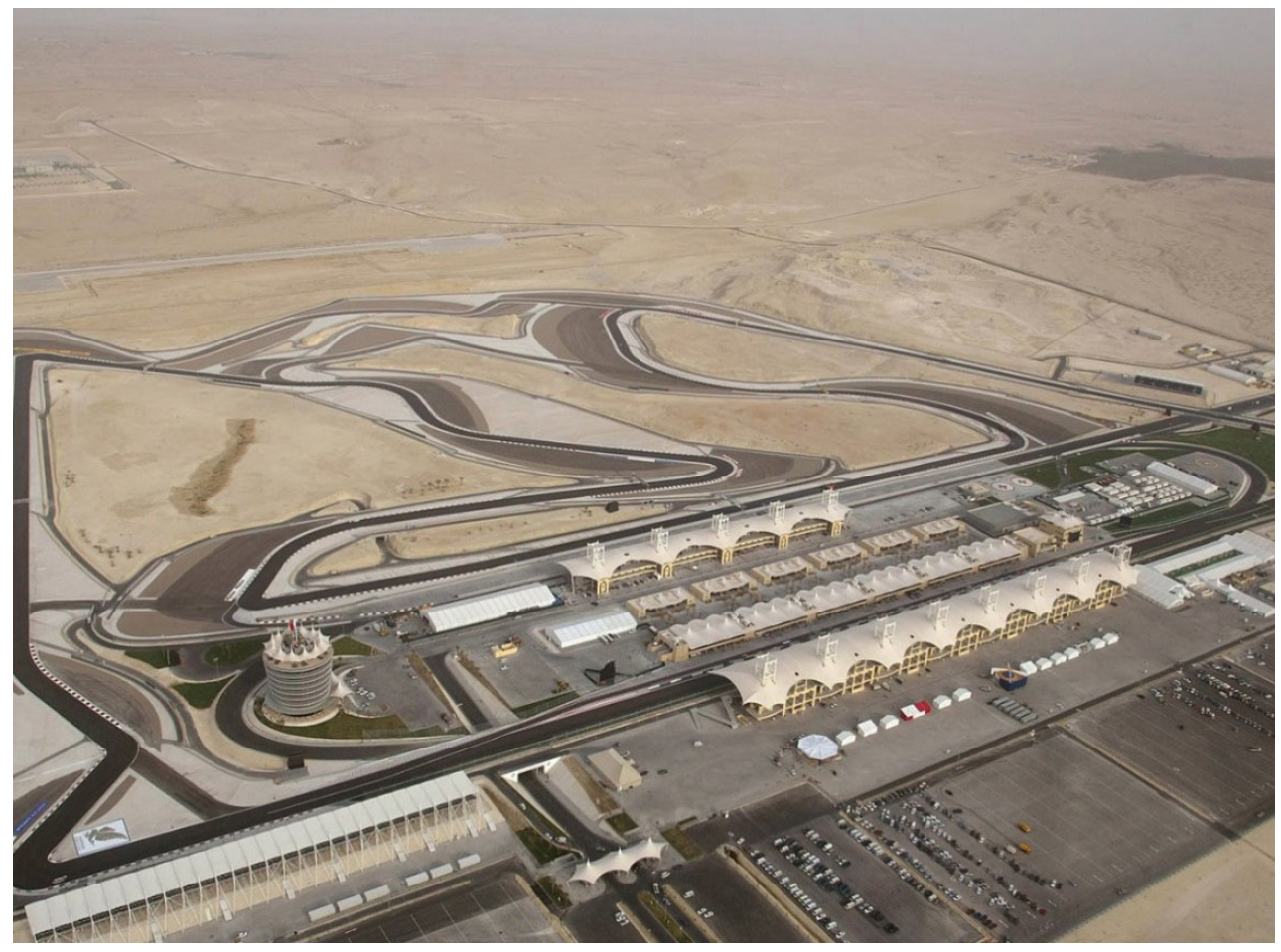

Figure 1. Aerial shot of Bahrain FORMULA-1 Circuit project.

races have been hosted in the Kingdom of Bahrain, in 2004 and 2005. The FORMULA-1 Circuit had recently won the award of the best international racing car circuit. The Bahrain FORMULA-1 Circuit (as illustrated in Fig. 2) has a total capacity for 50,000 spectators. The racing circuit includes amongst others, a 9-storey VIP tower (Sakhir Tower as shown in Fig. 3); a main grandstand for 10,000 spectators and first-class hospitality suites; dedicated buildings for 18 international racing teams; a technical resource centre; administration buildings and broadcast centre; a second pit building with lounges and grandstand for 3,000 spectators, under track pedestrian and vehicle tunnels and a medical centre. Fig. 4 shows the picture of the Oasis Complex.

In the initial stage, 34 contractors from the Middle East, Europe, United States of America, China and Australia submitted their bids to secure the project. This number was then shortlisted to 9 international contractors and lastly the project was awarded to a Bahrain-Malaysia joint venture construction company. The project was considered successful because it was completed earlier than the allotted time and has attained the stringent quality control of race-track and building construction. This paper focuses on the reasons in which a construction firm from a developing economy can penetrate the international market in terms of securing the project and subsequently delivering the project deliverables successfully, in which case, a rare feat and not by accident. 


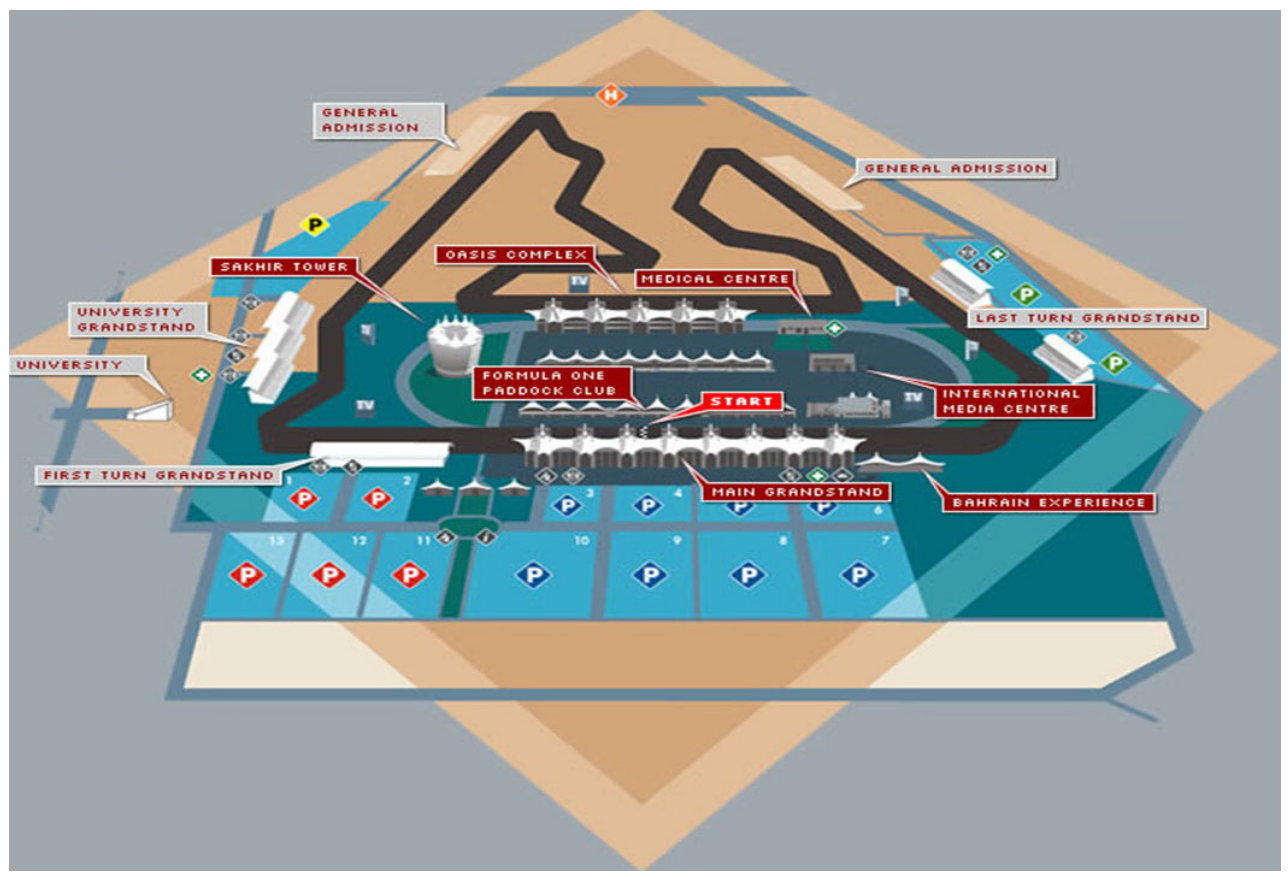

Figure 2. A Plan view of the Bahrain FORMULA-1 Circuit.

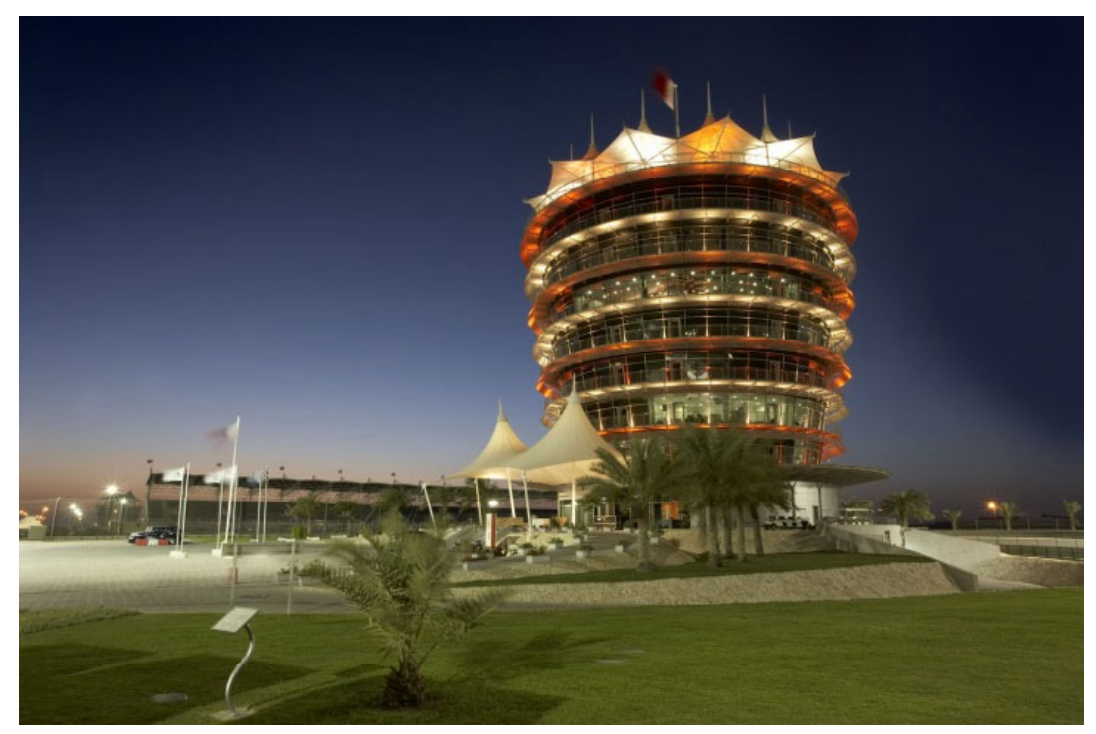

Figure 3. Sakhir tower in Bahrain FORMULA-1 Circuit. 


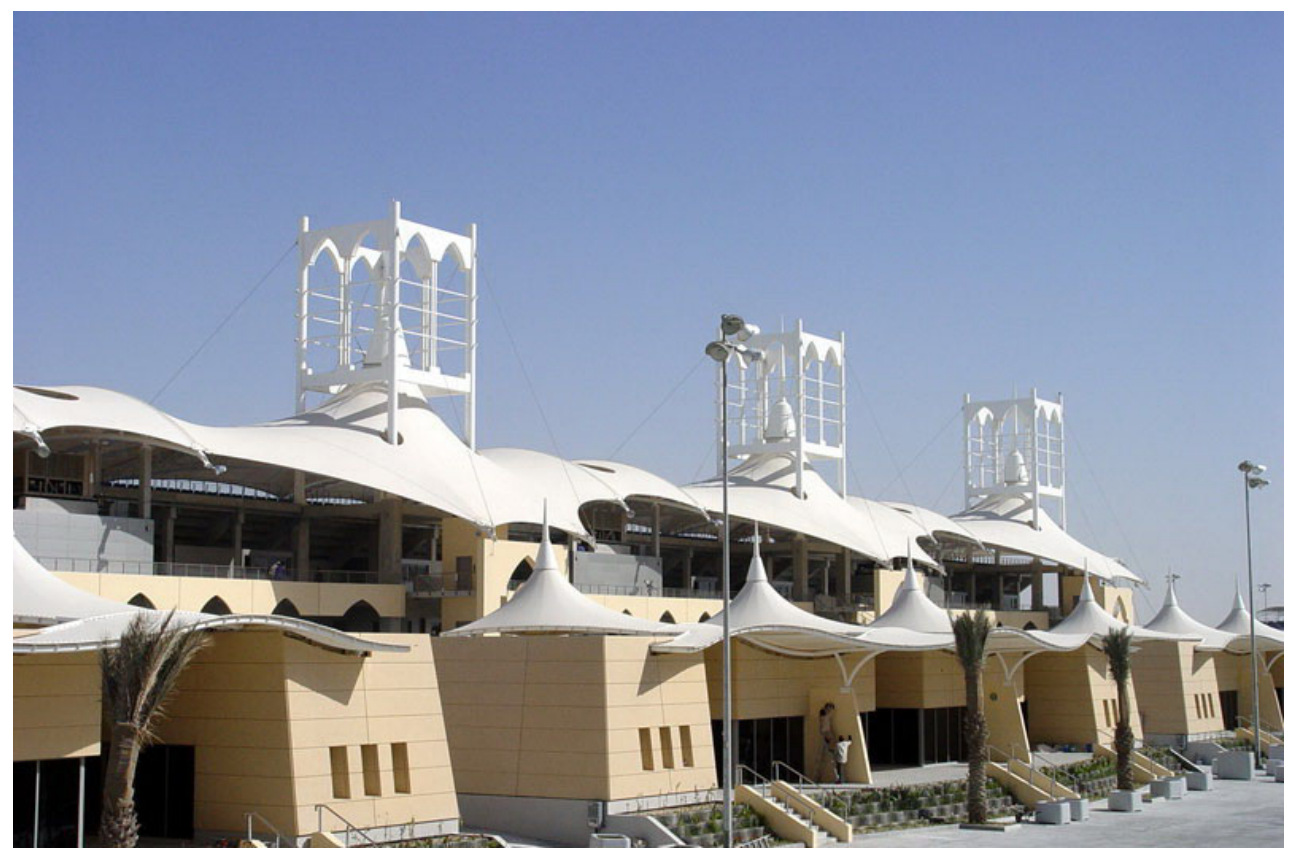

Figure 4. Oasis Complex in Bahrain FORMULA-1 Circuit.

\section{Determinants for success in international construction projects}

The definition of international project has evolved for the past twenty years (Halawa et al. 2013). Strassman and Wells (1988) defines an international construction project as one undertaken by an enterprise outside its home-country, for example, firms from one country building under contract in another country. However, this definition is not appropriate nor is it sufficient to depict the workings of the global market today. This definition should include projects in homecountry but involving foreign firms as competitors (West 1992, El-Sayegh 2008, Momaya and Selby 1998). There exists a construction market where construction work is undertaken by the international construction system comprising firms operating throughout the world (Adams and Fuss 2010, Drewer 2001, Li 2013). Due to the location specificity of construction outputs, construction industry is 'local' by nature in terms of climate, regulations, political, institutional and social conditions that exist in a particular locality (Ozorhon et al. 2007, Hillerbrandt 2000). This inadvertently gives competitive advantage to home-grown firms over foreign contractors in terms of language, culture, taxation charges, currency restrictions and project logistics in terms of securing networks of local suppliers and sub-contractors (Flanagan 1994). The global construction market has been estimated to be about USD 3, 000 billion annually and around one-third of this figure has been undertaken by the international construction system (Bon and Crosthwaite 2000). 


\subsection{International players}

The international construction market has been dominated by contractors from a few developed countries (ENR 1991, 1992, 2000, World Bank 2000). An analysis was done on the figures depicted in the annual Engineering News-Record (ENR) survey on the top 30 international contractors during 1999 to 2000 worldwide. Fifty-eight contractors were listed at least once in this group during the period; the highest number were American contractors, followed by Japanese, French, British, and German. Some firms which do not belong to developed countries have also made significant participations in the international market. Five firms from Korea (middle-income) and China (low-income) were among the 30 top international firms in 1990-2000. During the period of 1990 to 2000, only one construction firm from Malaysia has been ranked in the top 225 contractors in ENR. This Malaysian firm was Pilecon Engineering Berhad, ranked 180th in 1993. The number of international firms from middle-income and developing countries such as Brazil, China, Cyprus, Korea and Turkey has increased from year 2000 onwards. Their firm-specific advantages are access to inexpensive, highly skilled labour proficient in available technology and close geographical, cultural, and language proximity to their markets (Kim 1988, Strassman and Wells 1988, Adams 2008, Rashid 1990). In addition, some authors highlight the support from their governments including credits, export guarantees, preferential taxes, and other export development incentives (Han et al. 2010, Quak 1990, Betts and Ofori 1994, Abdul-Rahman and Berawi 2002).

\subsection{Prerequisites for competitiveness}

In order to succeed in the international market, there are certain criterions for a construction firm to develop beforehand. Kindleberger (1969) suggests that for foreign firms to break down local companies' advantages there must be some imperfection in the local markets for goods or factors of production, or interference in competition by governments or firms, which separates markets (Kindleberger 1969). The typically large, complex and one-off nature of construction projects means privileged access to key inputs, in particular, skilled labour and capital, are crucial. The United Nations Centre for Transnational Corporations (UNCTC 1989) observes that technical knowledge rather than capital investment is the most important barrier to entry and competitiveness in international construction. Access to the most efficient means of production, cheapest and best building materials and engineering knowledge that may have not been proprietary but had not yet been appropriated by others were instrumental in the early international success factors of European and US contractors (Linder 1994, Dikmen, Birgonul, and Han 2007). Like other business enterprises, construction companies choose oversea markets where they have competitive advantage based on firm and national advantages (Adams and Fuss 2010, Seymour 1987, UNCTC 1989). Firm specific advantages include: the firm's name, which embodies its reputation, experience and expertise; and firm size, which relates to its resources. 
National advantages include: national currency; geographical proximity to market(s); historical, political, language, cultural and economic relationships between the home and the host countries; foreign direct investment by homecountry enterprises; and strengths of inter-sectoral linkages within the home country's economy (Seymour 1987, UNCTC 1989). Internationalizing contractors must possess certain prerequisites, which include the firm's track record, corporate knowledge, communication structures, resources, and risk management capability. Some authors (Flanagan 1994, Ustinovichius et al. 2010, Rashid 1990, Ofori 2003, CSSC 1989) categorized the key factors contributing to competitiveness in international construction, namely: human resources and their management; technology; and government's incentives and disincentives. Management expertise is considered the most important because of the peculiarities and problems of overseas projects.

\subsection{Determinants of success for international construction}

There are models available to analyse international construction from the perspective of the construction firm itself; the country in which the construction firm originate from; and from the countries that host the international construction projects, respectively (Zhao et al. 2013). In such analysis it would be relevant to consider the four determinants in Porter's diamond (Porter 1985) as well as culture and institutional arrangements and government's influence ("chance" would be an exogenous variable) as a starting point for both the firm and the host country's construction industry. This type of study is commonly done at the macro level, whereby the aggregate total of works procured from international contractors residing in a particular country is tabulated and analysed, and the micro level, which is at each firm's competitiveness. Oz (2001) and Yates et al. (1991) have used the Porter's Diamond model in analysing the performance of international Turkish contractors and the US construction industry with regard to future international competition, respectively. The study in Turkey shows that Turkish contractors have comparatively low labour costs in the markets that they penetrated. Turkish contractors also had geographical and cultural proximity to these markets and religious advantage in countries like the Middle East and North Africa. On the other hand, problems encountered included financial and administrative difficulties; lack of coherent government policies and excessive bureaucracy in the respective countries where the construction work is done.

Other models that have been used in analysing international construction include the classic product-market matrix for strategy formation proposed by Ansoff (1965); core competences concept by Pralahad and Hamel (1990); and the engineering idea of Hammer and Champy (1993). Several authors have also borrowed concepts from behavioural models, which focus on the motivations and decision-making including: management, which is exemplified by the work of Aharoni (1966); industrial organization theory, which argues that the multinational enterprise (MNE) possesses features enabling it to overcome entry barriers into foreign markets and giving it comparative advantages, as exemplified 
by Kindleberger (1969) and Hymer (1976); the internalization theory of business enterprises applied to MNE by Buckley and Casson (1976); and general theories such as Dunning's (1977) eclectic paradigm. On the other hand, some authors (Hasegawa 1988, Han et al. 2010, Momaya and Selby 1998) have analysed issues surrounding international construction without much reference to the existing models. This was done by Hasegawa (1988) when he considered the international strategies of Japanese construction firms and identified two sources of competitive forces: the level of domestic and international construction, and the threat of new entrants to industry through diversification. Momaya and Selby (1998) quantified the international competitiveness of the Canadian construction industry and compared it with those of its Japanese and United States counterpart.

Most of the analytical frameworks used in explicating the reasons for international competitiveness recognize the difference between international construction and multi-national manufacturing by encompassing the specific features of construction in general and international construction projects in particular (Ofori 2003, Dikmen, Birgonul, and Gur 2007). One example of specific features in construction would be the project-based nature of construction which renders medium-term alliances within a cluster of firms possible. Another example is the location specificity of construction projects, which makes it necessary for firms to have strong abilities in logistics and communications; to develop means of shortening the learning curve of acquiring knowledge regarding the domestic working practices, and also to secure the commitment of the suppliers in the materials supply chain. Third, the construction process is fragmented and each project involves several firms with different corporate objectives and experiences (Jia et al. 2013). In short, the risks and difficulties facing firms in construction projects are vast and varied, but these adversities are exacerbated when these firms enter the international market arena.

\subsection{Earned Value Analysis (EVA) project monitoring methods}

Project performance monitoring and forecasting are supported by project learning activities and the level of lesson learned is related to inter-project learning (Kerzner 2001). Abba (1996) stated earned value analysis (EVA) is a management technique that relates the learning to technical performance. However, Czarnigowska (2008) defined earned value (EV) as a well-known project management tool that uses information on cost, schedule and work performance to establish the current status of the project. One reason for EVA method not being widely accepted in construction is because project managers lack in understanding the concept of EVA (Kim et al. 2003). Anbari (2003) mentioned that there might be important lessons to learn from each step or formulas in terms of estimating, budgeting, performance management, and cost control in EVA. Reallocation of organizational resources might be another outcome from EVA (Lewis 2001).

The basic concept of EVA has not changed for three decades since its inception (Brandon 1998, Daniel 1985, Fleming and Koppelman 2002, Howes 2000). EVA is used for forecasting of project cost and schedule at completion and highlights 
the possible need for corrective action (Kim et al. 2003). According to Anbari (2003), the inputs of EVA are periodically monitored actual expenditures and physical scope accomplishments such as the planned value, earned value, and actual cost. On the other hand, the outputs of EVA are cost and schedule predictions along with performance indices such as the schedule performance index and cost performance index. EVA is also defined as a management technique that relates resource planning and usage to schedules and to technical performance requirement and to bring cost and schedule variance analysis together to provide managers with a more accurate status of a project (Kim et al. 2003). EVA is the methods used to measure and communicate the real physical progress of a project taking into account the work complete, the time taken, and the costs incurred to complete that work (Fleming and Koppelman 2002, Iranmanesh and Mokhtari 2008).

\section{Bahrain FORMULA-1 Circuit in Literatures}

Alnaser et al. (2006) studied the energy and environmental considerations in Bahrain FORMULA-1 Circuit. The noise level emitted from vehicles on the circuit during the Formula-1 event, on April 4th 2004, was acceptable and caused no physical disturbance to the fans in the VIP lounges or to scholars studying at the University of Bahrain's Shakeir Campus, which is only $1.5 \mathrm{~km}$ away from the circuit. The sound-intensity level (SIL) recorded on the balcony of the VIP lounge was $128 \mathrm{~dB}(\mathrm{~A})$ and was $80 \mathrm{~dB}(\mathrm{~A})$ inside the lounge. The calculated SIL immediately outside the lecture halls of the University of Bahrain was $70 \mathrm{~dB}(\mathrm{~A})$ and $65 \mathrm{~dB}(\mathrm{~A})$ within them. Thus racing at the FORMULA-1 circuit can proceed without significantly disturbing the academic-learning process. The purchased electricity demand by the circuit complex peaked (at $4.5 \mathrm{MW}$ ) during the first FORMULA-1 event on April 4th 2004. The reverse-osmosis (RO) plant at the BIC provides $1000 \mathrm{~m} 3$ of desalinated water per day for landscape irrigation. Renewable-energy inputs, (i.e., via solar and wind power), at the FORMULA-1 circuit could be harnessed to generate electricity for water desalination, air conditioning, lighting as well as for irrigation. If the covering of the FORMULA-1 circuit complex was covered by adhesively fixed modern photovoltaic cells, then $1.2 \mathrm{MW}$ of solar electricity could be generated. If two horizontal-axes, at $150 \mathrm{~m}$ height above the ground, three $75 \mathrm{~m}$ bladed, and wind turbines were to be installed, then the output could reach $4 \mathrm{MW}$. Furthermore, if 10,000 Jojoba trees (a species renowned for having a low demand for water, needing only five irrigations per year in Bahrain and which remain green throughout the year) are planted near the circuit, then the local micro-climate would be improved with respect to human comfort as well as the local environment becoming cleaner.

Alnaser et al. (2007) studied the architectural, construction and environmental matters in Bahrain FORMULA-1 Circuit. This is what makes the project very special and appropriate for different car race functions and activities. The roofing 
system of tents and construction details show how modern materials have been mounded to achieve buildings with indigenous Bahraini characteristics. Employing tents above the stands and some buildings satisfies not only functional and climatic requirements, but also achieves a pleasing visual appearance. The circular 8-storey VIP tower, with increasing floor area, the higher the story, acts as a prominent landmark. The inclinations of the walls of the media centre and race tower make them appear to grow elegantly out of the ground, while the colours of their cladding ensures they integrate well with their surroundings. The variety of shapes of the buildings, and especially of their roofs, provides an interesting skyline. Using a Teflon membrane to cover $10800 \mathrm{~m}^{2}$ of roofing provides shading and hence decreases the insulation (the incident solar radiation) input, which otherwise could reach $1100 \mathrm{~W} / \mathrm{m} 2$ on a horizontal surface in mid-June, with $80 \%$ direct and 20\% diffuse solar radiation. This lowers the interior-cooling load: such a design has been employed successfully in the King Fahad Stadium in Saudi Arabia.

\section{Research methods and procedures}

\subsection{The procedures}

A 12-month case study was conducted as a qualitative process to identify the international competitiveness of a Malaysian construction firm performed in the Bahrain FORMULA-1 Circuit project. The objectives of this case study are to determine the specific pre-requisites of securing workload from the international market, to explore the criterions that ensured smooth delivery of the project deliverables of time, cost and quality, within the context of performing in an international environment, and to understand the interplay of these criterions in the context of adversity and risks associated with large projects and international markets. The research team worked as a technical consulting team attached to the Malaysian main contractor. The data collected for this research are primary data. The method of case study was selected due to the specialized nature of the construction of Formula One tracks and the rich detail of data that was made accessible to the researchers. The case study method can investigate different kinds of evidence: evidence which is there in the case setting and which has to be abstracted and collated to get the best possible answers to the questions (Yin 1994, Creswell 1994, Bryman 2004). Open discussions were performed on both parties of the International Joint-Venture (IJV) entity, on matters regarding project management and the strategic decisions that were made in the course of the project. Key members of the design and construction team such as the race-track architect, the internal project manager, and senior engineering members of the IJV entity were working together with the research team. Documents and records of the construction project provided sufficient correspondence with the client. The time and cost monitoring flow charts used in the project has been studied. Document retrieval were conducted in both countries of Bahrain and Malaysia. 


\subsection{The project profile}

The brief information of this project is listed in Table 1. The track (its top view is shown in Fig. 5) was built on a 400-acre sandy plot of land in Sakhir 19 miles southwest of the island's capital, Manama. The site is between Al-Areen Wild Life Park and The University of Bahrain. The desert racing track was built on a 1.7 square $\mathrm{km}$ area. Designed by a German track specialist, the 70,000 spectator track is the first of its kind in the Middle East. The buildings surrounding the track, mainly the Sakhir Tower (Fig. 6 shows its photo in construction), the Oasis Complex and the Main Grandstand are based on Arab Architecture. Fig. 7 captures the construction site while the FORMULA-1 circuit project was under construction. Table 2 and Table 3 list the major facilities and quantities in Bahrain FORMULA-1 Circuit project. Table 4 lists the six different individual tracks in this project.

\section{Table 1. Brief information of Bahrain FORMULA-1 Circuit project}

Constitute

Total Floor Area $\left(\mathrm{m}^{2}\right)$

Roadworks and Paved areas

Electrical Works

Mechanical Works

Special Electronics

Planned Contract Value

Actual Contract Value

Client

Main Contractor

Planned Duration

Actual Contract Duration

Consultant
Total of 14 buildings consisting of Main Grandstand, Pit Building, Team Building, Multi Purpose Building, Media Centre, Medical Centre, VIP-Tower, Workshop, and other miscellaneous buildings. $50,526 \mathrm{~m}^{2}$ $302,722 \mathrm{~m}^{2}$ Asphalt Pavement $73,166 \mathrm{~m}^{2}$ Concrete Pavement $36,3856 \mathrm{~m}^{2}$ Parking Area (Bricks and Aggregates)

Main installation of wires, power installation, lighting, power distribution, fire alarm system, sound installation, telephone installation and earthing for all the buildings and related external works.

Plumbing, drainage, sanitary fittings, storm water disposal, storage tanks, fire fighting installation, lift installation, $\mathrm{A} / \mathrm{C}$ installation for all the buildings and associated external works.

Fibre optic network, UPS, video surveillance, digital video storage, camera tracing, public address system, signalling system, information displays, SMATV, time keeping, race control management, access control, telecommunication, fault indication system, security management system including all necessary cabling and controlling.

56,200,000 Bahrain Dinars

62,506,728 Bahrain Dinars

Ministry of Works, Kingdom of Bahrain

WCT Engineering Berhad, Malaysia

8th November 2002 to 5th March 2004 (16 months)

Tilke and Partners W.L.L. 


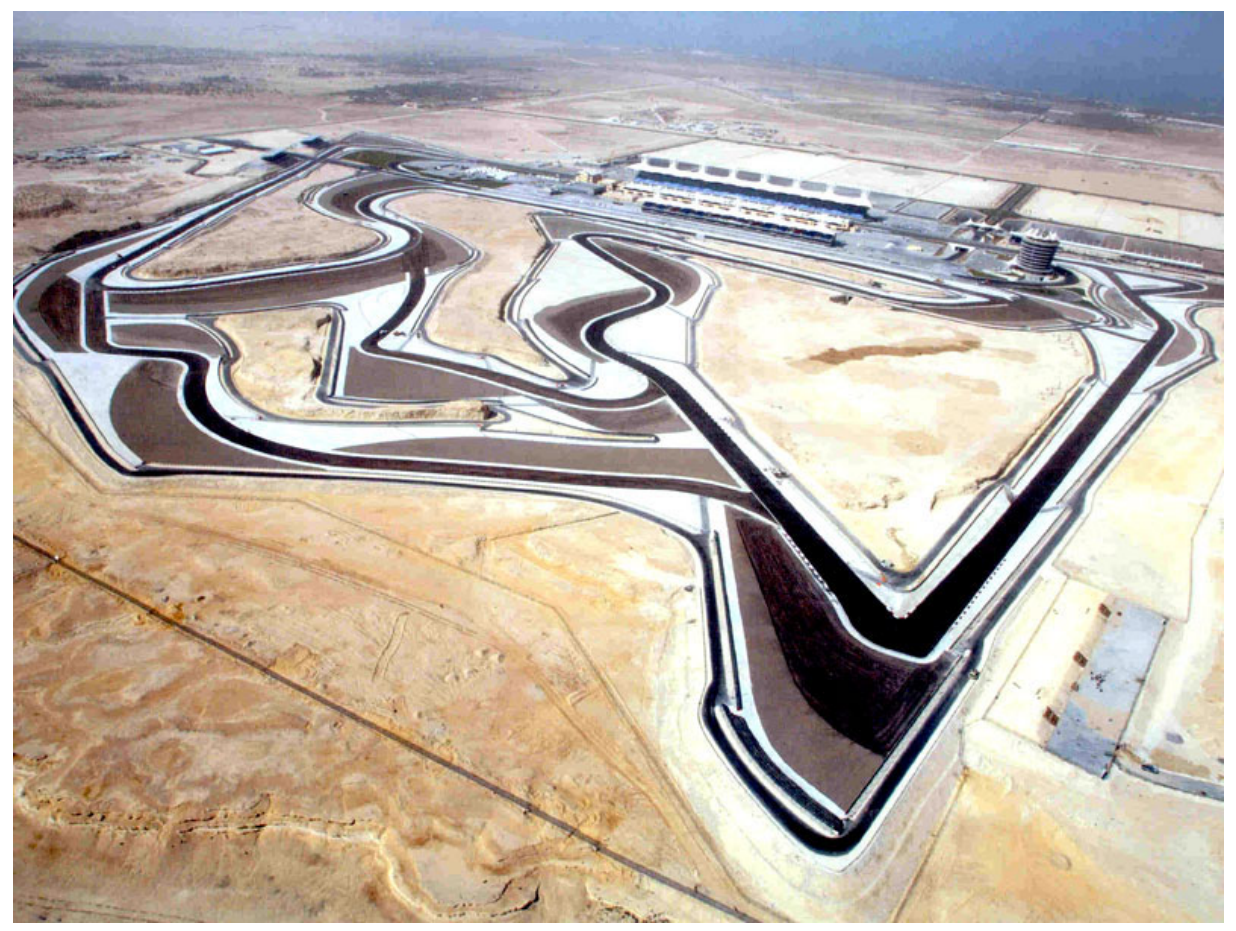

Figure 5. Top view of the tracks.

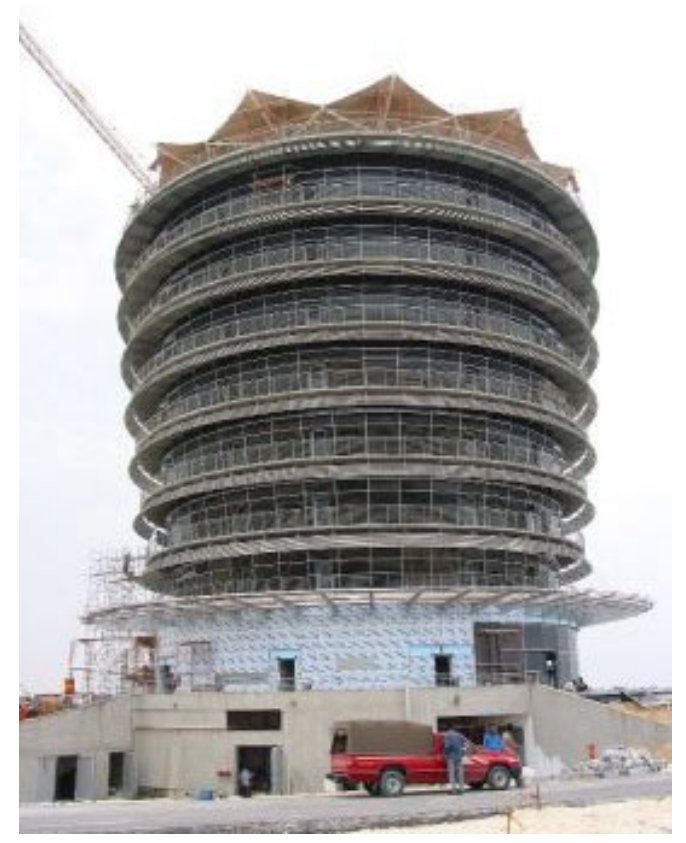

Figure 6. Sakhir Tower in construction. 


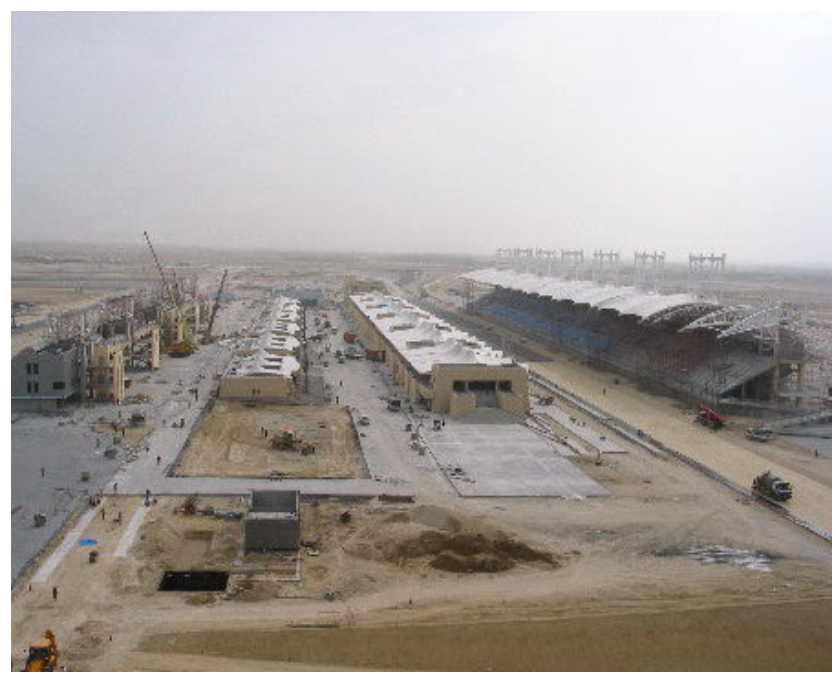

Figure 7. Bahrain FORMULA-1 Circuit project under construction.

Table 2. Facilities in Bahrain FORMULA-1 Circuit project

\begin{tabular}{l|l}
\hline Facilities & Areas $\left(\mathrm{m}^{2}\right)$ \\
\hline Main Grandstand & 20,000 \\
Pit Building & 18,000 \\
Multi-Purpose Building & 12,000 \\
VIP Tower & 7,500 \\
Team Buildings & 5,000 \\
Media Centre & 1,750 \\
Medical Centre & 450 \\
Workshop Building & 850 \\
Plant Building & 1,000 \\
Entrance Gates (3 buildings) & 150 \\
Workers' Lodging Building & 450 \\
\hline
\end{tabular}

Table 3. Major quantities of Bahrain FORMULA-1 Circuit project

\begin{tabular}{ll}
\hline Major Parts & Quantities \\
\hline Total built up area & $65,000 \mathrm{~m}^{2}$ \\
Concrete & $70,000 \mathrm{~m}^{3}$ \\
Rock excavation & $730,000 \mathrm{~m}^{3}$ \\
Soft excavation & $120,000 \mathrm{~m}^{3}$ \\
Track asphaltic works & $104,000 \mathrm{~m}^{2}$ \\
Services road asphaltic works & $154,000 \mathrm{~m}^{2}$ \\
Asphalt run off & $70,000 \mathrm{~m}^{3}$ \\
Gravel run off & $65,000 \mathrm{~m}^{3}$ \\
Tensile roofing & $31,000 \mathrm{~m}^{2}$ \\
Triple guardrail & $12,000 \mathrm{~m}$ \\
Single guardrail & $6,000 \mathrm{~m}$ \\
\hline
\end{tabular}


Table 4. Six different individual tracks in Bahrain FORMULA-1 Circuit project

\begin{tabular}{l|l|c|c|c}
\hline No. & Track & Length $(\mathrm{km})$ & Width $(\mathrm{m})$ & No. of Turns \\
\hline 1 & Grand Prix Track (main racing track) & 5.41 & $14-22$ & 16 \\
2 & Inner Track & 2.55 & $13-15$ & 8 \\
3 & Outer Track & 3.664 & $13-17$ & 10 \\
4 & Drag Strip & 1.2 & 18.5 & $\mathrm{n} / \mathrm{a}$ \\
5 & Test Oval & 2.5 & $14-22$ & $\mathrm{n} / \mathrm{a}$ \\
6 & Paddock Circuit & 3.6 & $14-22$ & 9 \\
\hline
\end{tabular}

\section{Research findings and discussions}

The findings concentrate on the salient features that helped both the host contractor and the foreign contractor win the tender in the Bahrain construction market and the success factors toward the challenges in international joint venture.

\subsection{Winning the tender: the pre-requisites for entering the international market}

The host contractor, an established medium-sized Bahrain construction company, was interested in participating in the construction of the Bahrain FORMULA-1 Circuit. However, the Bahrain contractor (the 'Host Contractor' in this partnering) has no experience in building race tracks, so that they did a preliminary survey on race track specialists contractors. They found that the Malaysian contractor (the 'Foreign Contractor' in this partnering) had completed the Sepang FORMULA-1 Circuit in Malaysia successfully with recorded savings from the initial contract sum and was also appointed as a consultant in an FORMULA-1 circuit project in China. Based on the Foreign Contractor's track record and experience, the Chief Executive Officer (CEO) of the Host Contractor initiated preliminary discussions to the Managing Director (MD) of the Foreign Contractor in order to explore the possibilities of working together for the BFC project.

The Host Contractor's commitment and knowledge of the incoming BFC project brought the Foreign Contractor's key personnel to Bahrain to perform a market analysis and a risk analysis on the salient features of the local construction operating environment. Both sides exchanged views and information on supplychain issues including: sub-contracting practices, labour force and the materials supply-sector; financial feasibility and the financial sector's support system; and the government's requirements regarding joint ventures specifically. Both the Foreign Contractor and the Host Contractor performed a two-way compatibility and capacity analysis of their respective technical expertise, experience, knowledge and relationships with the local construction environment before a final agreement between them was made. The Foreign Contractor had confirmed that the local conditions were politically and financially stable. Both sides were satisfied and confident that the risks are manageable and that the partnership would produce a positive outcome so that they decided to sign a joint-venture 
agreement. Upon satisfaction of the fact that the local conditions were politically and financially stable and that the Host Contractor's technical expertise, experience, knowledge and relationships with the local construction environment is commendable, the Foreign Contractor concluded that the initiative to work together with a local partner for the BFC project is predicted to be successful.

The joint venture was formulated based on equal shareholding and sharing of profits. This International Joint Venture (IJV) entity qualifies them to enter the pre-qualification exercise done by the Government of Bahrain to those companies who want to enter the bidding process. One of the conditions put forward by the Government of Bahrain was that the entity must have home-country contractors' participation in the consortium or IJV. From the outset both parties have agreed mutually the specific goals of the project, namely: 1) maximize cooperation and mutual trust to develop a win-win culture, 2) reduce the administrative costs and contractual conflict through less adversarial relationships, 3) reduce errors and wastage on site by exploring superior project planning and construction methods, and 4) reduce the overall project costs and time but maintain good quality of constructed items, as shown in Table 5.

The first task for the IJV was to put forward a bid for the BFC project which formed part of a pre-qualification exercise of Contractors performed by the Client. Table 6 listed the major tendering documents used in the bidding stage. The prequalification exercise brought the number of Contractors qualified for the final bid down to nine. At this stage the client imposed a stricter condition of raising the bid bond by USD 40 million. It was at this stage that the knowledge of the Host Contractor on the country's policies, regulations and practices became very valuable. After considering the new condition, the Contractor took a calculated risk to bid in for the work for about USD 150 million. It was a calculated risk because a bid of USD 150 million will not cover all risks that a Contractor might encounter while working in an international context; it is a relatively low bid.

Table 7 lists competitive bidding records on the public tendering day. Without the experience and knowledge from the Host Contractor on the institutional working practices and procedures of their own country, the Contractor would have wanted to insure himself against most elements of project risks and this would have led to a higher bid price. The Contractor was awarded the BFC project because they were the lowest bid. The high level of trust in each other's

Table 5. Specific goals agreed by Host Contractor and Foreign Contractor for BFC project

\begin{tabular}{l|l}
\hline \multicolumn{1}{c}{ Focus } & \multicolumn{1}{c}{ Goals } \\
\hline Cooperation & $\begin{array}{l}\text { To maximize cooperation and mutual trust to develop a win-win culture } \\
\text { To reduce the administrative costs and contractual conflict through less } \\
\text { adversarial relationships }\end{array}$ \\
Errors \& Wastage & $\begin{array}{c}\text { To reduce errors and wastage on site by exploring superior project plan- } \\
\text { ning and construction methods }\end{array}$ \\
Time, Cost \& Quality & $\begin{array}{c}\text { To reduce the overall project costs and time but maintain good quality of } \\
\text { constructed items }\end{array}$ \\
\hline
\end{tabular}


Table 6. Constitute of tendering documents

\begin{tabular}{|c|c|}
\hline Volumes & Items Included \\
\hline Volume 1 & $\begin{array}{l}\text { Instructions to Tenders, Forms of Contract Agreement, Conditions of Contract, and } \\
\text { Form of Tender }\end{array}$ \\
\hline Volume $2 \mathrm{~A}$ & $\begin{array}{l}\text { Measurement preamble, Preliminaries and Schedule of rates (Architectural/ } \\
\text { Structural and Civil Works) }\end{array}$ \\
\hline Volume 2B & Schedule of Rates for Electro-mechanical works \\
\hline Volume $3 \mathrm{~A}$ & $\begin{array}{l}\text { Particular Specification of Architectural, Structural works and Civil engineering } \\
\text { works }\end{array}$ \\
\hline Volume 3B & Particular Specification for Electro-mechanical works, special equipment and spares \\
\hline Volume 4A & Schedule of Drawings \\
\hline Volume 4B & Contract Drawings \\
\hline
\end{tabular}

Table 7. Competitive bidding records on the public tendering day

\begin{tabular}{l|l|l|l|l|l|l}
\hline No & Bidders & $\begin{array}{c}\text { Basic } \\
\text { (Bahrain } \\
\text { Dinars) }\end{array}$ & $\begin{array}{c}\text { Basic+C.T. } \\
\text { (Bahrain } \\
\text { Dinars) }\end{array}$ & $\begin{array}{c}\text { Alt.Addendum- } \\
\text { 6 (Bahrain } \\
\text { Dinars) }\end{array}$ & Comments & Nation \\
\hline 1 & Bidder 1 & $58,500,000$ & $59,981,174$ & n/a & With 10\% AP & Bahrain \\
2 & Bidder 2 & $75,227,475$ & $77,901,761$ & $57,382,251$ & With 10\% AP & UAE \\
3 & Bidder 3 & $71,879,237$ & $74,483,770$ & n/a & n/a & Malaysia \\
4 & Bidder 4 & $69,138,122$ & $71,138,122$ & n/a & With 10\% AP & UAE \\
$\mathbf{5}$ & Bidder 5 (win) & $\mathbf{5 6 , 2 0 0 , 0 0 0}$ & $\mathbf{5 8 , 2 8 0 , 0 0 0}$ & $\mathbf{5 2 , 2 0 0 , 0 0 0}$ & With 10\% AP & Malaysia \\
6 & Bidder 6 & $64,210,748$ & $65,530,748$ & n/a & With 10\% AP & UAE \\
7 & Bidder 7 & $59,162,029$ & $61,330,317$ & $58,473,317$ & With 10\% AP & Saudi Arabia \\
8 & Bidder 8 & $78,979,775$ & $81,864,775$ & n/a & With 10\% AP & Germany \\
9 & Bidder 9 & $61,188,275$ & $63,794,602$ & $61,914,602$ & With 10\% AP & Saudi Arabia \\
\hline
\end{tabular}

competence between the two main protagonists (the MD of the Foreign Contractor and the CEO of the Host Contractor) was one of the main reasons the bid was successful.

\subsection{Leadership and team structure in WCT}

The main contractor applied the matrix structure in its team organization, which owned advantages such as being efficient, strong project focus, easier postproject transition, and flexible. The matrix project team structure of WCT (MainCon) is illustrated in Fig. 8. Leadership, human resources and their deployment has been cited as one of the main determinants of competitive advantage in international construction (CSSC 1989, International Construction Task Force 1993, Flanagan 1994). The two main protagonists of the IJV were leading the construction project with a clear project clarity and demarcation of work. The level of trust in each other's ability to manage their own respective skills and resources was reflected very well during the course of the project. This type of mutual dependency has created a workable and efficient business structure offering mutual benefits for both parties. 


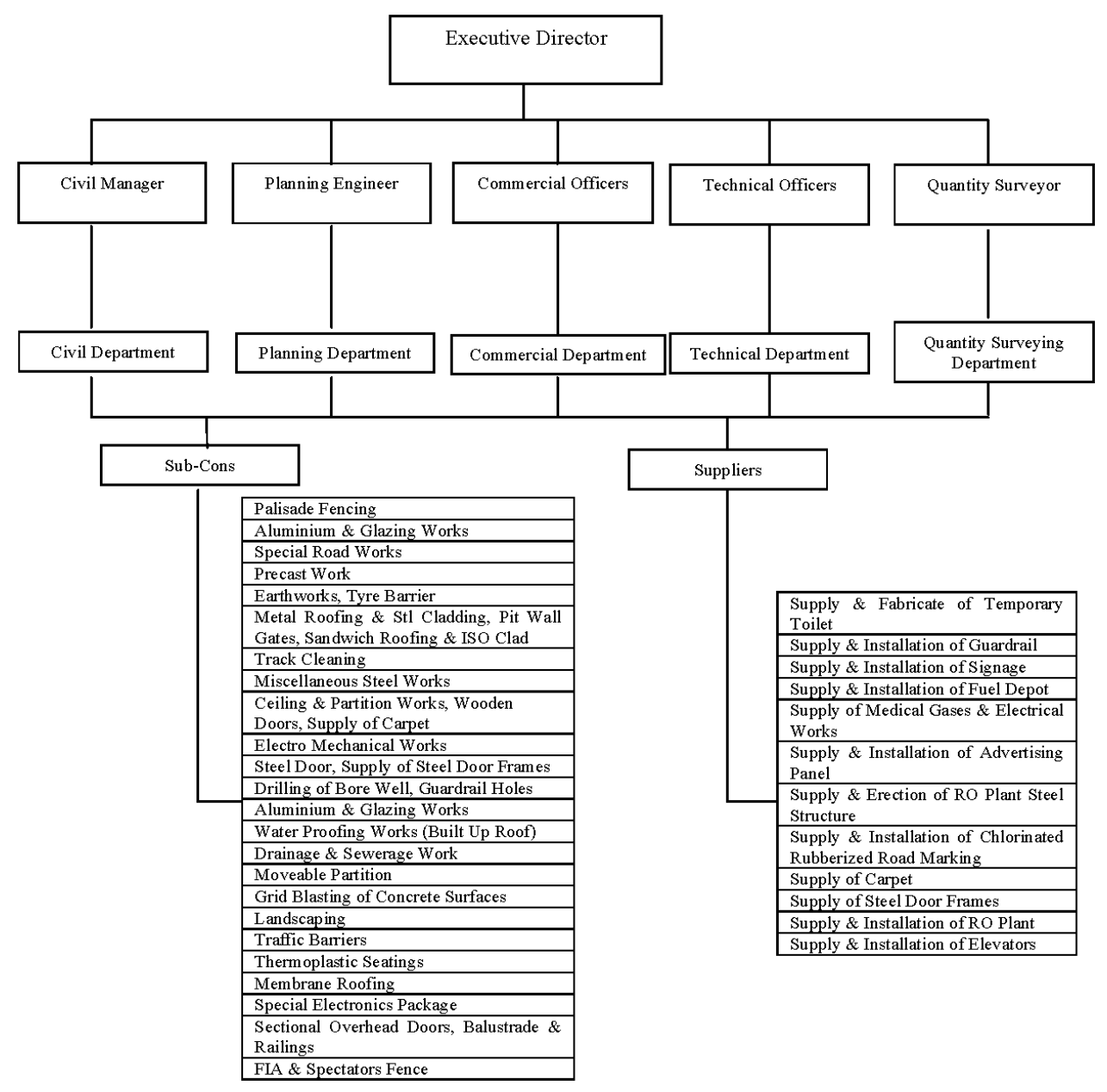

Figure 8: Matrix project team structure of WCT (Main-Con).

Speed of delivery was of high priority to the project so that the fast track construction mode was adopted. The challenges and difficulties of doing work on fast track was exacerbated when the project handover date was brought forward from August 2003 to April 2003 as the actual FORMULA-1 race was brought forward to an earlier date. Construction work had to be accelerated and more general workers were taken on board to manage the acceleration order. The full commitment by the top management made sure that all decision making on site was done as quickly as possible and this was crucial in developing the much needed sense of urgency in the whole project environment.

The project was not only done at accelerated time but also the magnitude of work production involved was high, averaging up to USD7 Mil monthly and at its peaked of USD18 Mil. However, the contractors have managed to deliver the BFC 
project within the reduced time of 16 months with 400 variations. Instead of adhering rigidly to the contract and getting the entitlement of extension of time (EOT) with the 400 variations order, the contractors have agreed mutually with the client to convert the EOT into monetary incentives. These factors of the reduction of the construction period and the incomplete design submitted by the consultants have motivated the contractors to take extra precaution of stocking up construction materials. Instead of estimating the quantity of material needed at $5 \%$ wastage, a percentage of $20 \%$ was adopted in order to eliminate the risk of material shortages. In terms of manpower, a decision was made that extra labourers will be hired to reduce the risk of workforce shortage. This exercise was deemed necessary by the Contractors, because extra precaution was needed in order for newly hired labour to increase their efficiency by way of interaction with the more knowledgeable and existing workforce.

These strategic decision-making and tactical moves by the Contractors in solving problems as these problems surfaced was detrimental to their financial commitment in the project. However the Contractors understood the importance of working within the stipulated time frame and was transparent to the Client in terms of the extra financial risks that they have taken to facilitate the needs of the Client. The importance of the client's objectives was made as priorities of the Contractors' organizations as well. This direction from the top management of the Contractors' entity made the construction side very flexible in their work routine and material procurement much to the benefit of the client. Due to the fact that the Contractors are consistently pro-active in trying to solve problems on site; albeit technical problems or materials management, the work of the project management team on behalf of the Client becomes more efficient. In this sense the gap between the project management day-to-day decision-making by the Client's representative and the strategic decisions of the Contractor to facilitate the site facilities and project logistics were bridged.

\subsection{The flexibility of the IJV's project management structure}

The Foreign Contractor's technical expertise and efficient decision-making on site were their main strengths in most projects that they have worked in (AbdulRahman and Mohd-Rahim 2006). Their accumulated experience working in major infrastructure and building projects in Malaysia have equipped them with highly dedicated and trained personnel. All of these critical personnel: planning engineers, site engineers, civil and structural engineers, quantity surveyors, construction and project managers, were transported to Bahrain for the BFC project. The IJV formed the top level of construction and project managers incorporating both entities' personnel.

In designing and structuring the BFC project organization, the IJV identified and formalized project members into effective teams, and linking the processes and teams to manage on-site operations. It was a relatively flat organizational structure where only three main tiers of organizational levels were created. The system of formal authority within the organizational structure was facilitated by a 
continuous system of informal communication flow. There were frequent site meetings and updating on the project progress to all the work groups on site.

A substantial amount of specialist work was done by foreign sub-contractors that came from outside of Bahrain, such as from Malaysia, Germany and Saudi Arabia. Major sub-contractors involved in this project are listed in Table 8. Due to these complex procurement practices, the construction site had multi-national and diversified gangs of labourers at any one time. This was a new challenge to the IJV as they had to coordinate all activities efficiently so that no imported specialist gang came at the inappropriate period that renders their arrival redundant due to the fact that the previous work has not been completed. The IJV's project planning and tracking software system was critical in helping them plan the project logistics with some measure of accuracy and efficiency.

The Contractors paid particular attention to project coordination and planning in order to minimize the risks of material and labour shortage. The planning of construction activities provided the basis for the estimation of time period and costing for each work activity; and also a basis for claims evaluation for any extension of time entitlements. All work activities were coordinated in the appropriate sequence and proper lag time was given if some work is depended on foreign sub-contractors. The Contractor also contacted the sub-contractors and

Table 8. Sub-cons in Bahrain FORMULA-1 Circuit project

\begin{tabular}{c|l|l}
\hline $\begin{array}{c}\text { Sub- } \\
\text { contractor }\end{array}$ & \multicolumn{1}{c}{ Sub-Con Work description } & \multicolumn{1}{c}{$\begin{array}{c}\text { Port of } \\
\text { Origin }\end{array}$} \\
\hline Sub-con 1 & Palisade Fencing & Bahrain \\
Sub-con 2 & Aluminium \& Glazing Works & Bahrain \\
Sub-con 3 & Special Road Works & Bahrain \\
Sub-con 4 & Precast Work & Bahrain \\
Sub-con 5 & Earthworks, Tyre Barrier & Bahrain \\
Sub-con 6 & Metal Roofing \& Stl Cladding, Pit Wall Gates, Sandwich Roofing & Bahrain \\
& \& ISO Clad & \\
Sub-con 7 & Track Cleaning & Bahrain \\
Sub-con 8 & Miscellaneous Steel Works & Bahrain \\
Sub-con 9 & Ceiling \& Partition Works, Wooden Doors, Supply of Carpet & Bahrain \\
Sub-con 10 & Electro Mechanical Works & Malaysia \\
Sub-con 11 & Steel Door, Supply of Steel Door Frames & Bahrain \\
Sub-con 12 & Drilling of Bore Well, Guardrail Holes & Bahrain \\
Sub-con 13 & Aluminium \& Glazing Works & Bahrain \\
Sub-con 14 & Water Proofing Works (Built Up Roof) & Bahrain \\
Sub-con 15 & Drainage \& Sewerage Work & Bahrain \\
Sub-con 16 & Moveable Partition & Bahrain \\
Sub-con 17 & Grid Blasting of Concrete Surfaces & Bahrain \\
Sub-con 18 & Landscaping & Saudi Arabia \\
Sub-con 19 & Traffic Barriers & Bahrain \\
Sub-con 20 & Thermoplastic Seatings & Bahrain \\
Sub-con 21 & Membrane Roofing & Malaysia \\
Sub-con 22 & Special Electronics Package & Germany \\
Sub-con 23 & Sectional Overhead Doors, Balustrade \& Railings & Saudi Arabia \\
Sub-con 24 & FIA \& Spectators Fence & Bahrain \\
\hline & & \\
\hline
\end{tabular}


invited their feedback in terms of making sure that the schedule put forward was an achievable target for each sub-contractor respectively.

\subsection{Construction and managing the supply chain}

Table 9 lists the suppliers involved in Bahrain FORMULA-1 Circuit project. In the construction process, the IJV identified three main challenges that they had to overcome during the duration of the project. The first challenge is the site condition of the project. Due to the nature of the race track project, there will be an extensive amount of earthworks and rock blasting due to the fact that the site was predominantly covered with big rocks. A reduction of the excavation level from the original design was executed due to an error in the design, which resulted in a changed order of $1,500 \mathrm{cu}$ meters of rocks blasted, leading to a total of 1 million cu $\mathrm{m}$ of rock excavated. There is only one rock blasting company in Bahrain and the Host Contractors of the IJV negotiated efficiently so that the former will not behave opportunistically in the advert of unforeseen events. The weather had also affected the performance during hot summer periods. Productivity was low due to very hot weather that warrants longer resting hours. This was overcome by employing more workers to work in shifts and overtime when the temperature was cooler.

The second challenge was the specification of materials by both the Client and the FORMULA-1 race track requirement. The project specified the usage of steel, special polished stone, polymer modified bitumen that are not readily available in Bahrain. This then needed the facilities of the IJV to procure materials and the specialist contractors from other countries. Large amounts of steel, up to 8,500 tons were needed for the building works. Due to the construction boom in Bahrain, there was a shortage of steel, which had to be overcome by importing over 1,000 tons of steel from Malaysia. Steel for steel structures were sourced from Korea, Malaysia and United Kingdom and sent to subcontractor steel plant in Malaysia to be fabricated before being sent back to Bahrain.

In terms of technological complexities, the Fédération Internationale de l'Automobile (FIA) ordered special polished high quality aggregates to be used for

Table 9. Suppliers in Bahrain FORMULA-1 Circuit project

\begin{tabular}{l|l|l}
\hline Supplier & \multicolumn{1}{|c}{ Supply Work description } & Port of Origin \\
\hline Supplier 1 & Supply \& Fabricate of Temporary Toilet & Bahrain \\
Supplier 2 & Supply \& Installation of Guardrail & Bahrain \\
Supplier 3 & Supply \& Installation of Signage & Bahrain \\
Supplier 4 & Supply \& Installation of Fuel Depot & Bahrain \\
Supplier 5 & Supply of Medical Gases \& Electrical Works & Bahrain \\
Supplier 6 & Supply \& Installation of Advertising Panel & Bahrain \\
Supplier 7 & Supply \& Erection of RO Plant Steel Structure & Bahrain \\
Supplier 8 & Supply \& Installation of Chlorinated Rubberized Road Marking & Bahrain \\
Supplier 9 & Supply of Carpet & Bahrain \\
Supplier 10 & Supply of Steel Door Frames & Bahrain \\
Supplier 11 & Supply \& Installation of RO Plant & Bahrain \\
Supplier 12 & Supply \& Installation of Elevators & Bahrain \\
\hline
\end{tabular}


the wearing course of the tracks. Not being available locally, an amount of 10,000 $\mathrm{cu} \mathrm{m}$ of the aggregates had to be imported from Malaysia and 2,000-3,000 cu m were imported from Wales. The Bahrain track surface also saw the first time use of styrene butadiene styrene (SBS) polymer modified bitumen with a mix of aggregates and incorporating a calcined bauxite powder. This had also posed a challenge to the construction team. The bitumen had to be imported from Singapore in drums. By the time they reached Bahrain, they had hardened and had to be decanted and melted down. A special plant was constructed to decant and boil the bitumen. Adding to the challenge, the project consultants found the bitumen substandard despite confirmation from the supplier that all was in order prior to export. Special additives, calcined bauxite powder had to be ordered from Singapore to improve the quality of the bitumen to the consultant's satisfaction.

The delivery of bitumen was delayed due to logistics problem caused by the Iraq War. Cargo ships were difficult to get and ports were congested. Deliveries were rerouted and the cargoes were not covered by insurance. The total risks were borne by the contractors. Most of the project's materials were sourced from outside Bahrain such as from the Middle East, Korea, United Kingdom, Malaysia and Singapore. The same goes for the building fabrics, which had to be sourced from Europe and sent to Malaysia before the Malaysian subcontractor constructed them in Bahrain. Other works such as the internal partitions, guardrails and mechanical and electrical works were also subcontracted to Malaysian subcontractors.

The third challenge for the project was manpower. As mentioned above, most specialist work was procured from outside of Bahrain. The number of foreign general workers from India, Pakistan and Sri Lanka totalled to about 1000 people. The supervision of both specialist workers and general workers went well despite there being 3,000-5,000 workers on site at peak times. The inability of workers from India, Pakistan and Cyprus to understand the English or Arab language forced the project leaders/managers to be present on-site most of the time to resolve conflicts and other site issues.

\subsection{Project monitoring and other salient factors}

Project management is a process which consists of planning, organizing, scheduling and controlling all aspects of a project and the motivation of all those involved in it to achieve specific project goals and objective on time and to the specified cost, quality and performance. Amongst major problems in construction projects are the cost overrun and delay. For instance, cost overruns of $25-33 \%$ are common in the construction industry. In order to mitigate the overrun cost and delay in construction project, project managers need to use effective and powerful tools and techniques to forecast the status of project during construction stage. One such method believed to be effective is the earned value analysis (EVA). According to Fleming \& Koppelman (2002), EVA is the best indicator of future performance and therefore by using trend data it is possible to forecast cost or schedule overruns at quite an early stage in a construction project. EVA addresses many project management areas including project organizing, planning, schedul- 
ing and budgeting, accounting, analysing, reporting and change controlling (Anbari 2003). The Bahrain FORMULA-1 Circuit project team applied the EVA methods for project monitoring, by which an EVA flow chart the project team had attempted to use is illustrated in Fig. 9.

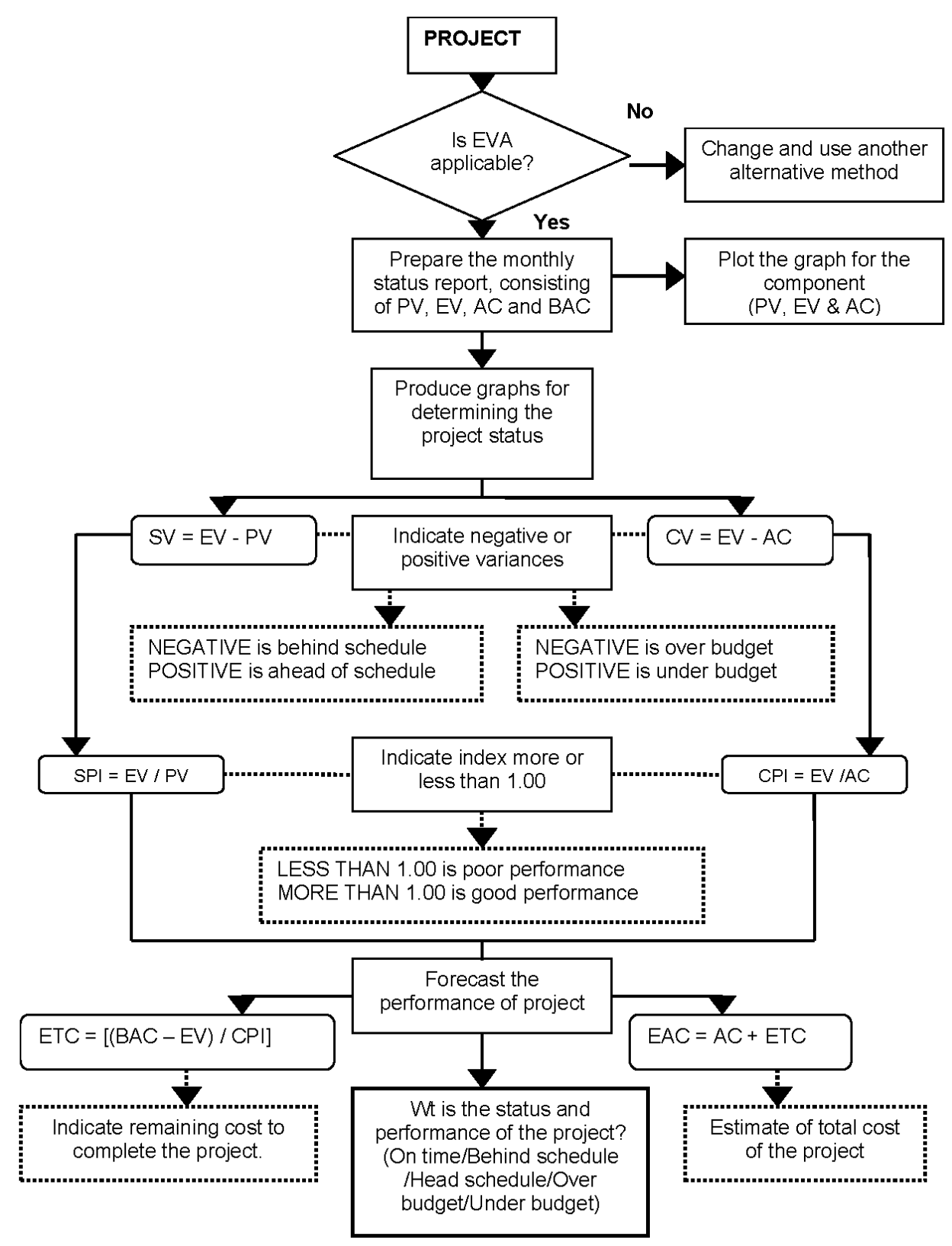

Figure 9. EVA project monitoring flow chart used in Bahrain FORMULA-1 Circuit project. 
Cultural differences between partners of an IJV entity can reveal different management styles and tolerances, which could lead to misunderstandings, create ambiguities and also mistrust in the relationship (Daniels and Radebaugh 1998). The Foreign Contractor, though not Muslims themselves, originated from Malaysia where the official religion is Islam. In this sense, they were already privy with the knowledge and subtleties of working within the context of Islamic practices. For example, meetings will not interfere with the praying times and small temporary praying facilities were built on site. The Foreign Contractor's high level of sensitivity for their partner's religious practices gained the trust and respect from the Host Contractor's personnel and this consequently produced a good working relationship between the two parties.

The recognition that the project was on a fast track motion prompted the Contractors to resort to some tactical decisions in order to minimize the risks of not delivering the project to the Client on time. The Contractors announced to the critical materials suppliers that if they can deliver $75 \%$ of the contracted material on time, then they will be paid in full at that stage. This was a good incentive for the materials-supply companies to quickly deliver all the required materials in order to get full payment. In this sense the Contractors needed strong financial backing from the banks to maintain sufficient working capital during the course of the project. Financial support was forthcoming and not a problem due to the fact that both contractors of the IJV have had a sound and good relationships with the banks during their previous work in other projects.

\section{Conclusions and recommendations for future research}

International Joint Ventures (IJVs) are mostly project-specific. The case study revealed that the success of the BFC project was the product of several factors, namely: 1) advanced technical and engineering expertise 2) selection of a committed partner 3) management expertise 4) creating and sustaining a good working environment 5) appropriate risk management 6) maintaining a reliable international materials supply chain, and 7) efficient project planning and tracking system. Management expertise is considered to be the most important factor because of the peculiarities and problems of international projects. This calls for flatter organizational structure implying less bureaucracy, time and confusion, enabling the IJV to act quickly to solve problems during the course of the project. The BFC project has witnessed direct involvement by the top management of the IJV from the pre-qualification until the commissioning stage. The high levels of commitment and trust within the top management personnel have given a positive influence to the working relationship of both parties' personnel of the joint venture outfit. Apart from the financial gains of participating in international construction projects, the BFC project has provided the opportunity for the two contractors to work together for the first time. This successful endeavor has enabled the IJV to continuously seek projects within the Middle-East region that is fast developing in 
its infrastructure and building projects. Future researches are recommended to study the universality of those success factors and the EVA decision flow chart discovered for IJV in international partnering projects.

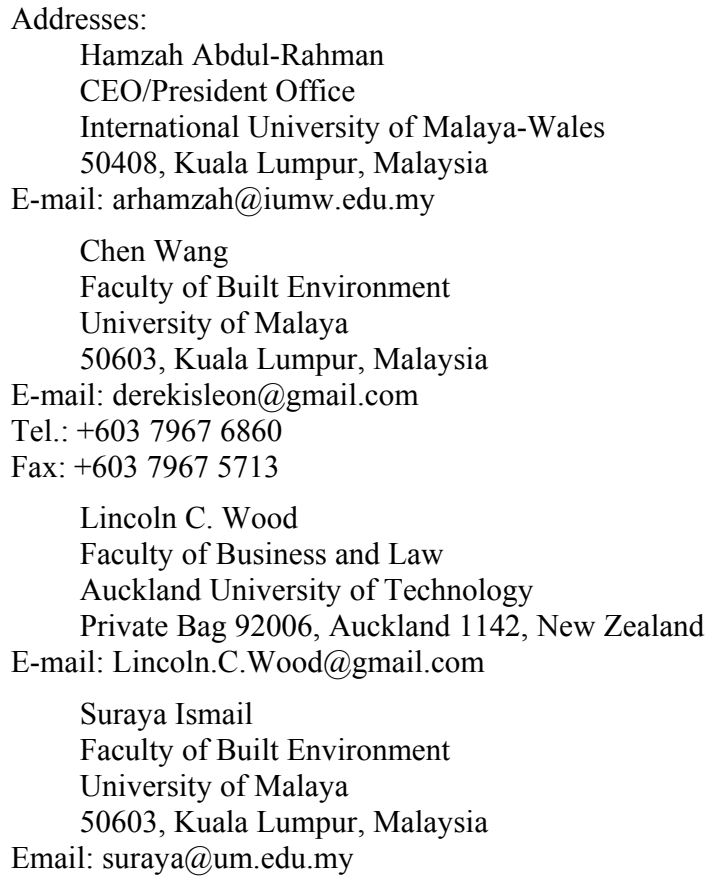

\section{References}

Abba, W. F. (1996) "Earned Value Management: reconciling government and commercial practices". Program Manager 26, 58-67.

Abdul-Rahman, H. and F. Mohd-Rahim (2006) Challenges and opportunities of international construction. Kuala Lumpur: University of Malaya Press.

Abdul-Rahman, H. and M. A. Berawi (2002) "Managing change in construction contracting". Contract Management 42, 10-16.

Adams, F. K. (2008) "Risk perception and Bayesian analysis of international construction contract risks: the case of payment delays in a developing economy". International Journal of Project Management 26, 2, 138-148.

Adams, Z. and R. Fuss (2010) "Macroeconomic determinants of international housing markets". Journal of Housing Economics 19, 1, 38-50.

Aharoni, Y. (1966) The foreign investment decision process. Boston, MA: Harvard University Press.

Alnaser, W. E., S. D. Probert, S. El-Masri, S. E. Al-Khalifa, R. Flanagan, and N. W. Alnaser (2006) "Bahrain's Formula-1 racing circuit: energy and environmental considerations". Applied Energy 83, 352-370.

Alnaser, N. W., R. Flanagan, S. E. Al-Khalifa, R. Mumtaz, S. El-Masri, W. E. Alnaser (2007) "Architectural, construction and environmental matters of Bahrain's International Formula 1 Circuit”. Building and Environment 42, 1783-1794. 
Anbari, F. T. (2003) "Earned value project management method and extensions". Project Management Journal 34, 4, 12-23.

Ansoff, I. H. (1965) Corporate strategy. New York: McGraw-Hill.

Bradon, J. and M. Daniel (1998) "Implementing earned value easily and effectively". Project Management Journal 29, 2, 11-18.

Bryman, A. (2004) Social research methods. 2nd ed. New York: Oxford University Press.

Betts, M. and G. Ofori (1994) "Strategic planning for competitive advantage in construction: the Institutions". Construction Management and Economics 12, 203-217.

Buckley, P. J. and M. C. Casson (1976) The future of the multinational enterprise. London: Macmillan.

Bon, R. and Crosthwaite, D. (2000) The future of international construction. London: Thomas Telford.

CSSC (1989) Investing in building 2001. University of Reading, Reading: Centre for Strategic Studies in Construction.

Chou, J. and J. Yang (2013) "Evolutionary optimization of model specification searches between project management knowledge and construction engineering performance". Expert Systems with Applications 40, 11, 4414-4426.

Creswell, J. W. (1994) Research design: qualitative and quantitative approaches. California: Sage Publications.

Czarnigowska, A. (2008) "Earned Value as a tool for project control". Budownictwo i Architektura 3, $2,15-32$.

Daniels, J. D. and L. H. Radebaugh (1998) International business: environments and operations. Burr Ridge, IL: McGraw-Hill.

Daniel, R. M. (1985) "Earned value technique for project performance". Journal of Management in Engineering 1, 2, 79-94.

Dikmen, I., M. T. Birgonul, and S. Han (2007) "Using fuzzy risk assessment to rate cost overrun risk in international construction projects". International Journal of Project Management 25, 5, 494-505.

Dikmen, I., M. T. Birgonul, and A. K. Gur (2007) "A case-based decision support tool for bid markup estimation of international construction projects". Automation in Construction 17, 1, 30 44.

Drewer, S. (2001) “A perspective on the international construction system". Habitat International $25,1,69-79$.

Dunning, J. H. (1977) "Trade, location of economic activity and the MNE: a search for an eclectic approach". In The International Allocation of Economic Activity, 395-418. B. Ohlin, P. O. Hesselborn, and P. M. Wijkman, eds. London: Macmillan.

El-Sayegh, S. M. (2008) "Risk assessment and allocation in the UAE construction industry". International Journal of Project Management 26, 4, 431-438.

ENR (1991) "The top 250 international contractors: Instability slows growth abroad". Engineering News-Record 22 July, 30-43.

ENR (1992) "The top 250 international contractors: firms set sail for hot markets". Engineering News-Record 24 August, 34-45.

ENR (2000) "The top 225 international contractors: slow growth, high hopes". Engineering NewsRecord 14 August, 48-87.

Flanagan, R. (1994) "The features of successful construction companies in the international construction market". In Strategic planning in construction: proceedings of the A. J. Etkin international seminar on strategic planning in construction companies. (A. Warzawski, and R. Navon.) Haifa, Israel, 8-9 June, 304-318.

Fleming, Q. W. and J. M. Koppelman (2002) "Using earned value management". Cost Engineering $44,9,32-36$.

Halawa, W. S., A. M. K. Abdelalim, and I. A. Elrashed (2013) "Financial evaluation program for construction projects at the pre-investment phase in developing countries: a case study". International Journal of Project Management 31, 6, 912-923. 
Han, S. H., D. Y. Kim, H. S. Jang, and S. Choi (2010) "Strategies for contractors to sustain growth in the global construction market". Habitat International 34, 1, 1-10.

Hasegawa, F. (1988) Built by Japan: competitive strategies of Japanese construction industry. New York: Wiley.

Hammer, M. and J. Champy (1993) Reengineering the corporation: a manifesto for business revolution. London: Brierley.

Hillerbrandt, P. M. (2000) Economic theory and the construction theory. 3rd ed. Basingstoke: MacMillan.

Howes, R. (2000) "Improving the performance of earned value analysis as a construction project management tool". Journal of Construction and Architecture Management 7, 4, 399-411.

Hung, A. L. W., G. M. Naidu, S. T. Cavusgil, R. C. Yam (2002) "An exploratory study of project based international joint ventures: the case of Chek Lap Kok Airport in Hong Kong". International Business Review 11, 505-522.

Hymer, S. H. (1976) The international operations of national firms: a study of direct foreign investment. Doctoral thesis, MIT Press, Cambridge, MA.

International Construction Task Force (1993) Competing in the global market. Austin, TX: Construction Industry Institute.

Iranmanesh, S. H. and Z. T. Hojati (2008) "Designing a progress simulator for estimation of project completion cost and time". In Proceedings of the international conference on project management (ICoPM), Petaling Jaya, Malaysia, November 18-20, 120-127.

Jia, G., X. Ni, Z. Chen, B. Hong, Y. Chen, F. Yang, and C. Lin (2013) "Measuring the maturity of risk management in large-scale construction projects". Automation in Construction 34, 5666.

Kerzner, H. (2001) Project management: a system approach to planning, scheduling, and controlling. 7th ed. New York: John Wiley \& Sons.

Kim, D. Y., S. H. Han, H. Kim, and H. Park (2009) "Structuring the prediction model of project performance for international construction projects: a comparative analysis". Expert Systems with Applications 36, 2, 1961-1971.

Kim, E. H., G. W. William, and R. D. Michael (2003) "A model for effective implementation of earned value management methodology". International Journal of Project Management 21, $375-382$.

Kim, S. (1988) "The Korean construction industry as an exporter of services". The World Bank Economic Review 2, 2, 225-238.

Kindleberger, C. P. (1969) American business abroad: six lectures on direct investment. New Haven: Yale University Press.

Lewis, J. P. (2001) Project planning, scheduling, and control: a hands-on guide to bringing projects in on time and on budget. 3rd ed. New York: McGraw-Hill.

Li, X. (2013) "TIMODAZ: a successful international cooperation project to investigate the thermal impact on the EDZ around a radioactive waste disposal in clay host rocks". Journal of Rock Mechanics and Geotechnical Engineering 5, 3, 231-242.

Linder, M. (1994) Projecting capitalism: a history of the internationalization of the construction industry. Westport: Conn.

Momaya, K. and K. Selby (1998) "International competitiveness of Canadian construction industry: a comparison with Japan and the United States". Canadian Journal of Civil Engineering 25, $640-652$.

Ofori, G. (2003) "Frameworks for analyzing international construction". Construction Management and Economics 21, 379-391.

Oz, O. (2001) "Sources of competitive advantage of Turkish construction companies in international markets". Construction Management and Economics 19, 135-144.

Ozorhon, B., D. Arditi, I. Dikmen, and M. T. Birgonul (2007) "Effect of host country and project conditions in international construction joint ventures". International Journal of Project Management 25, 8, 799-806.

Porter, M. E. (1985) Competitive advantage: creating and sustaining superior performance. New York: The Free Press. 
Pralahad, C. K. and G. Hamel (1990) "The core competence of the corporation". Harvard Business Review 3, 79-91.

Quak, S. K. (1990) Marketing abroad: exporting strategies for singapore construction firms. Singapore: Institute of South-East Asian Studies.

Rashid, A. A. (1990) Global strategies of construction firms. PhD thesis, University of Reading, Reading.

Seymour, H. (1987) The multinational construction industry. London: Croom Helm.

Strassman, P. and J. Wells (1988) Introduction: Global Construction industry. London: Croom Helm.

United Nations Centre for Transnational Corporations (UNCTC) (1989) Transnational corporations in the construction and design engineering industry. New York: United Nations.

Ustinovichius, L., G. Shevchenko, A. Barvidas, I.V. Ashikhmin, and D. Kochin (2010) "Feasibility of verbal analysis application to solving the problems of investment in construction". Automation in Construction 19, 3, 375-384.

West, R. C. (1992) "Improving international competitiveness". Journal of Professional Issues in Engineering Education and Practice 118, 2, 107-112.

World Bank (2000) World development record, 2000/01. Washington DC: World Bank.

Yates, J. K., S. Mukherjee and S. Nijos (1991) Anatomy of construction industry competition in the year 2000. (Source Document, 64.) Austin, TX: Construction Industry Institute.

Ye, K., L. Shen, J. Zuo (2013) "Utilizing the linkage between domestic demand and the ability to export to achieve sustainable growth of construction industry in developing countries". Habitat International 38, 135-142.

Yin, R. K. (1994) Case study research: design and methods. 2nd ed. (Applied Social Research Methods Series; 5.) California: Sage Publications.

Zhao, X., B. Hwang, and G.S. Yu (2013) "Identifying the critical risks in underground rail international construction joint ventures: case study of Singapore". International Journal of Project Management 31, 4, 554-566. 